\title{
A stereological study of the renal and adrenal glandular structure of red-legged partridge (Alectoris chukar)
}

\author{
N. Colcimen', G. Cakmak² \\ ${ }^{1}$ Department of Histology and Embryology, Faculty of Medicine, Van Yuzuncu Yil University, Van, Turkey \\ 2Department of Anatomy, Faculty of Veterinary Medicine, Van Yuzuncu Yil University, Van, Turkey
}

[Received: 4 December 2019; Accepted: 19 January 2020]

Background: Partridge is a major bird species that has recently gained an increasing importance as an alternative food source and a game animal in hunting tourism. Herein, we aimed to examine the histological structure and stereological properties of the renal and adrenal glands of red-legged partridge.

Materials and methods: Seven healthy adult red-legged partridges (Alectoris chukar) of both genders were used in this study. The Alectoris chukars were perfused with the intracardiac method and were kept in 10\% formaldehyde for $72 \mathrm{~h}$ for optimal fixation. The tissues were embedded in paraffin after routine light microscopic processes. Then, 5- $\mu$ m thick sections were taken, which were stained with haematoxylin and eosin, photographed, and examined in light microscope. Modified Cavalieri principle was used for volume calculation as stereological analysis. Total tissue volume ratios were calculated with the help of a point grid provided by the Shtereom 1.5 packaged programme. Mann Whitney-U test was used for inter-group comparisons. The significance level was set at 5\% SPSS (ver: 13) statistical software was used for all statistical analyses.

Results: Renal histological structure was found to resemble those of other bird species and contained a mixed type (mammalian, reptilian) glomerular structure. It was also found that the adrenal histology was not in the form of separate layers but composed of cell groups with different properties. Stereological renal volume assessment revealed statistically similar right and left renal size $(p>0.05)$. In adrenal gland volume assessment, the right and left adrenal volumes were also statistically similar ( $p>0.05)$.

Conclusions: The obtained data in the present study is thought to contribute to the understanding of the stereological, morphological and histological structure of the red-legged partridge (Alectoris chukar) kidney and adrenal gland. (Folia Morphol 2021; 80: 1: 210-214)

Key words: adrenal gland, kidney, partridge, stereology

\section{INTRODUCTION}

The partridge is the common name for belonging to the Alectoris and Perdix species of the Phasianidae family [4]. The partridge is a major bird species that has recently gained an increasing importance as an alternative food source and a game animal in hunting tourism.

The kidneys are located on both sides of the abdominal aorta and inferior vena cava in the dorsal part of the abdominal cavity, and the adrenal glands are

Address for correspondence: Dr. N. Colcımen, Van Yuzuncu Yil University, Faculty of Medicine, Department of Histology and Embryology, Van 65080, Turkey, e-mail: colcimennese@hotmail.com 


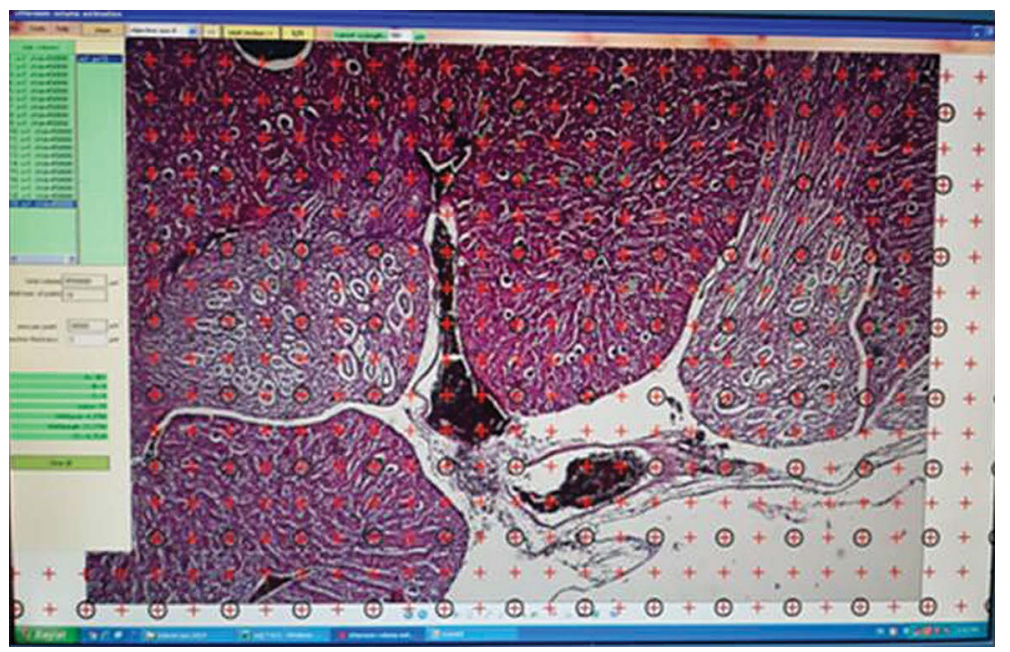

Figure 1. Transverse section of kidney photographed ( $\times 4$ objective) and a point counting grid superposed onto it for the volume calculation.

located on the cranial pole of both kidneys [16]. The kidneys of bird species have an intermediate structure between mammalians and reptilians. The bird species do not possess a renal pelvis, urinary bladder, or urethra [14]. Histologically, their kidneys have a multilobulated pattern and isolated cortex and medulla which are separated by a fine connective tissue. They have two types of nephron structures. The first one is designated as the mammalian or medullary type and is composed of a renal corpuscle, a proximal convoluted tubule, a distal convoluted tubule, a collecting tubule, and thin and thick segments of Henle's loop. The second type is the reptilian type also called as the cortical type, which has a smaller renal corpuscle but no Henle's loop; additionally, there is a short section between proximal convoluted tubule and distal convoluted tubule, which is named the intermediate tubule [13]. Adrenal glands are anatomic structures that play an important role for accommodation to all types of stress and, by hormones they produce, they contribute to many metabolic processes. In bird species the shape of the adrenal glands is highly variable, with inter-species and even inter-individual variations being possible. Experimental removal of adrenal glands results in death of birds [16]. It was showed in a review of the literature that there have been anatomic studies on red-legged partridge, but not specifically on its renal and adrenal gland structure. It was aimed to perform a detailed histological and stereological study of red-legged partridge's renal and adrenal glandular structures in this study.

\section{MATERIALS AND METHODS}

Seven healthy adult red-legged partridges (Alectoris chukar) of the both genders were used in this study. The animals were obtained from Van Yuzuncu Yil University Wildlife Protection Centre. It was approved by Van Yuzuncu Yil University Local Ethics Committee $(27 / 06 / 2019 / 06)$ complied with the study procedures. The partridges were anesthetised with $10 \mathrm{mg} /$ /kg Xylazine HCL (Rompun 2\%, $50 \mathrm{~mL}$, Bayer) and with 40 mg/kg i.m. Ketamine HCL (Ketalar 50 mg/mL, $10 \mathrm{~mL}$ vial, Pfizer). The animals were perfused with intracardiac method and dissected tissues were kept in $10 \%$ formaldehyde for $72 \mathrm{~h}$ for optimal fixation [18]. The tissues were embedded in paraffin after completion of routine histological light microscopy procedures. Then, 5- $\mu \mathrm{m}$ thick sections were obtained. The first section was randomly selected and then the $40^{\text {th }}$ section was taken. The sections were stained with haematoxylin and eosin, photographed, and examined in light microscope.

\section{Stereological analysis}

Stereology, random and systematic sampling is utilised to gain unbiased and quantitative information. Among stereological analyses, modified Cavalieri principle was used for volume calculation. Then, total tissue volume ratios were calculated using a point grid provided by the Shtereom 1.5 packaged programme (Fig. 1). Volume calculation was carried out using the following formula: $\mathbf{V}($ obj $)=t \times a / p \times \Sigma p$. $\mathrm{V}$ (obj) is the volume of the objective, $t$ is the section 
Table 1. Descriptive statistics and comparison of the results

\begin{tabular}{|c|c|c|c|c|c|c|c|c|c|c|c|}
\hline & \multicolumn{5}{|c|}{ Right } & \multicolumn{5}{|c|}{ Left } & \multirow[t]{2}{*}{$\mathbf{P}$} \\
\hline & Median & Mean & SD & Min. & Max. & Median & Mean & SD & Min. & Max. & \\
\hline Kidney tot. vol. [mm³] & 2.28 & 3.34 & 2.18 & 1.61 & 6.88 & 3.02 & 2.61 & 0.85 & 1.52 & 3.80 & 0.499 \\
\hline Cortex vol. [mm³] & 1.55 & 2.02 & 1.14 & 1.03 & 3.94 & 2.43 & 2.09 & 0.88 & 0.70 & 3.08 & 0.735 \\
\hline Kidney tot. vol./Cortex vol. [mm³] & 1.67 & 1.60 & 0.27 & 1.22 & 1.91 & 1.24 & 1.36 & 0.38 & 1.06 & 2.17 & 0.310 \\
\hline Medulla vol. [mm³] & 0.91 & 1.32 & 1.08 & 0.30 & 2.94 & 0.59 & 0.53 & 0.24 & 0.18 & 0.82 & 0.091 \\
\hline Kidney tot. vol./Medulla vol. [ $\left.\mathrm{mm}^{3}\right]$ & 2.50 & 3.24 & 1.53 & 2.10 & 5.52 & 5.14 & 6.60 & 4.93 & 1.85 & 16.74 & 0.176 \\
\hline Cortex vol./Medulla vol. [mm³] & 1.50 & 2.24 & 1.53 & 1.10 & 4.52 & 4.14 & 5.60 & 4.93 & 0.85 & 15.74 & 0.259 \\
\hline Adrenal gland tot. vol. $\left[\mathrm{mm}^{3}\right]$ & 0.02 & 0.02 & 0.01 & 0.01 & 0.03 & 0.02 & 0.02 & 0.01 & 0.02 & 0.03 & 0.499 \\
\hline
\end{tabular}

Max. — maximum; Min. — minimum; SD — standard deviation

thickness, $a / p$ represents the area of each point on the point counting grid and $\Sigma p$ is the total number of points hitting the renal and adrenal areas $[9,10]$. Coefficient of error (CE) and coefficient of variation (CV) were used to determine the optimum sample size in each group in the standard stereological approach [8]. The values of the CE and CV in our study were in accordance with the literature data.

\section{Statistical analysis}

Descriptive statistics included median, mean, standard deviation, minimum and maximum. Inter-group differences were analysed with Mann-Whitney $\mathrm{U}$ test. The significance level was set at $5 \%$. All statistical analyses were performed with SPSS (ver.13) statistical software package programme.

\section{RESULTS}

The stereological analysis revealed that the left and right kidneys had similar sizes. A stereological volume calculation showed a right renal volume of $2.28 \mathrm{~mm}^{3}$ and a left kidney volume of $3.02 \mathrm{~mm}^{3}$. Comparison of both renal volumes revealed a slight but statistically non-significant difference between both kidneys $(p>0.05)$ (Table 1). The microscopic examination of the histological sections demonstrated that the kidney was composed of lobules, each being composed of the cortical and medullary parts and encapsulated by connective tissue containing blood vessels. The renal structure was composed of $60 \%$ cortex and $40 \%$ medulla on the right side and $80 \%$ cortex and $20 \%$ medulla on the left kidney. The nephrons had structure two type of nephrons that the reptile and mammalian nephrons (Fig. 2). The number of reptilian nephrons was larger than the mammalian nephrons. The two nephron types also had different distributions so that they were more numerous in the cortex but there were only tubal structures in the medulla. The mammalian type nephrons were located in deep cortex, close to the medullary cone, whereas the reptilian nephrons were located in the peripheral and middle parts of the cortex, aligned in horseshoe shape around the central vein (Fig. 3).

Examination of the adrenal glandular structure showed that the left and right adrenal glands had some differences in shape but not in size, and a stereological volume assessment revealed that the volume of both adrenal glands was $0.02 \mathrm{~mm}^{3}(p>0.05)$ (Table 1). A general histological examination showed that the adrenal gland did not have three distinct different layers but only cellular differentiation (dark, light coloured; having different nuclear structures); the glands were encapsulated by a connective tissue containing blood vessels capsule separating them from the kidneys. The adrenal gland had a separate vascular supply (Fig. 4).

\section{DISCUSSION}

It was showed that the renal structure of red-legged partridge was similar to those of other bird species in this study. Red-legged partridge had two kidneys encapsulated by connective tissue containing blood vessels sheaths and composed of multiple lobules containing the cortical and medullar parts. The stereological volume assessment has shown that the right and left renal size were similar statistically. Previous studies on the right and left renal size of bird species have revealed variable results. One study reported that there were no difference between the right and left renal size [6] whereas another study reported difference between the left and right renal size [17]. Similarly, studies assessing the cortical and medullary volumes of bird species have reported variable results. A study has reported that $90 \%$ of the total 



Figure 2. A. Haematoxylin and eosin (H\&E) staining. Kidney nephron structure. The reptilian-type nephrons (black arrows). Scale bar $=50 \mu \mathrm{m}$; B. H\&E staining. The mammalian-type nephron. Scale bar $=50 \mu \mathrm{m}$.
Figure 3. A. Haematoxylin and eosin (H\&E) staining. The general appearances, lobular structure and vascularisation of kidney. Scale bar $=500 \mu \mathrm{m}$; B. H\&E staining. The histological structure of kidney. Medulla (white asterisk), cortex (black asterisk), horseshoe-shaped reptile glomerular structure (black arrow). Scale bar $=500 \mu \mathrm{m}$
Figure 4. A. Haematoxylin and eosin (H\&E) staining. The general appearance of the adrenal gland (arrow). Scale bar $=500 \mu \mathrm{m}$; B. H\&E staining. The adrenal gland structure and vascularization. Scale bar $=100 \mu \mathrm{m}$. volume of bird kidney was composed of the cortex and $2 \%$ of the medulla [3]; another one has reported corresponding figures of $77 \%$ and $10 \%$, respectively [19]. It was founded that the cortical ratio similar to the literature data, but the medullary ratio was slightly higher in this study. Casotti and Braun [5] reported that renal volume varied by the living environment of the bird species. Literature data suggest that a bird's renal shape, size, and structure change by its diet, phylogeny, and environmental factors [17].
All animals were in the same region and climatic conditions (maximum temperature $30-33^{\circ} \mathrm{C}$ ). The basic renal structure is composed of nephrons. The bird kidney is different from the mammalian one because it is composed of a two types of nephrons resembling mammalian and reptilian nephrons $[2,12]$. Similarly, in our study, two types of nephrons were observed. Prior studies have shown that more numerous reptile nephrons are located in the periphery of the lobule, a small renal corpuscle, and no loop 
of Henle. It has been reported that the mammalian nephrons are larger and had a more complex renal corpuscle and are located deep in the cortex neighbouring the medulla; additionally, they contain a loop of Henle, and are less in number [1]. Herein, it was shown a similar number and distribution of nephrons. The nephrons are responsible for filtration, reabsorption, and secretion, thereby forming urine. The bird's nephrons are composed of a glomerulus, a proximal tubule, a distal tubule, and collecting ducts [14]. This study also revealed similar results.

The present study demonstrated that the adrenal glands were located at the cranial pole of the kidneys and medial to them, as Nickel et al. [15] has reported. It was found the adrenal histology was not in the form of separate layers but composed of cell groups with different properties (having a dark or light colour and varying nuclear structure). It was also shown that the right and left adrenal glands had different shapes and there were also inter-individual differences. The adrenal gland was separated from the kidney tissue with a connective tissue sheath and had a separate vascular supply. The results of this study are in accordance with the previous studies on bird species [16]. Among the studies on adrenal gland size, Humayun et al. [11] and Wells and Wight [20] reported that the left adrenal gland was larger than the right one in chickens of both genders whereas Ozudogru et al. [16] as well as Elbajory [7] reported that the right adrenal gland was larger than the left one. The weight, length, width, and thickness of the adrenal glands vary by a number of factors, such as species, breed, age, health status, and environment [11]. In this study it was detected that there is no difference between stereologically calculated volumes between the right and left adrenal glands.

\section{CONCLUSIONS}

The obtained data in the present study is thought to contribute to the understanding of the stereological, morphological and histological structure of the red-legged partridge (Alectoris chukar) kidney and adrenal gland. We think that it will be a guide for the studies about red-legged partridge (Alectoris chukar).

\section{REFERENCES}

1. Akaydın Y, Ozcan Z. Hindi (Meleagris gallopavo) böbreğinin yapısı üzerinde ışık ve elektron mikroskobik çalışmalar. Ankara Üniv Vet Fak Derg. 2005; 52(1): 149-155, doi: 10.1501/vetfak_0000000047.
2. Aslan S. Üriner sistem. In, Aslan S (Ed): Kanatlı Histolojisi. Dora Basım Yayın Dağıtım, Bursa, Turkey. 2018: 85-98.

3. Batah AL. Morphological and histological study for the kidneys of coot bird (Fulica atra). Bas J Vet Res. 2012; 11(1): 128-136, doi: 10.33762/bvetr.2012.54767.

4. Can M, Ozdemir D. Kaya kekliği (Alectoris graeca) plexus sacralis'i üzerinde makro-anatomik araştırmalar. Kafkas Univ Vet Fak Derg. 2012; 18(1): 141-146, doi: 10.9775/ kvfd.2011.5226.

5. Casotti G, Braun E. Renal anatomy in sparrows from different environments. J Morphol. 2000; 243(3): 283-291, doi: 10.1002/(sici)1097-4687(200003)243:3<283::aidjmor5>3.0.co;2-b.

6. Dhyaa AA, Ali FR, Azhar SK, et al. Comparative anatomical and histological features of the kidney in harrier (Circus aueroginosus), chicken (Gallus domesticus) and mallard duck (Anas platyrhynchos). Iraqi J Vet Sci. 2014; 38(1): 107-113.

7. Elbajory SIA. Morphometric study of the adrenal gland of the adult Sudanese Chicken (Gallus domesticus) and Duck (Anas platyrhynchos). Cur Res J Biol Sci. 2012; 4: 239-241.

8. Gundersen HJ, Jensen EB. The efficiency of systematic sampling in stereology and its prediction. J Microsc. 1987; 147(Pt 3): 229-263, doi: 10.1111/j.1365-2818.1987. tb02837.x, indexed in Pubmed: 3430576.

9. Gundersen $\mathrm{HJ}$, Bendtsen TF, Korbo $L$, et al. Some new, simple and efficient stereological methods and their use in pathological research and diagnosis. APMIS. 1988; 96(5): 379-394, doi: 10.1111/j.1699-0463.1988.tb05320.x, indexed in Pubmed: 3288247.

10. Howard CV, Reed MG. Unbiased stereology, three-dimensionel measurements in microscopy. BIOS Scientific Publishers, Oxford, UK 1998: 39-68.

11. Humayun K, Aoyama M, Sugita S. Morphological and histological studies on the adrenal gland of the chicken (Gallus domesticus). J Poult Sci. 2012; 49(1): 39-45, doi: 10.2141/jpsa.011038.

12. Kocamıs H, Aslan S, Deprem T. Kazların böbrek yapısı üzerine histolojik ve histometrik inceleme. Kafkas Univ Vet Fak Derg. 2003; 9(2): 157-160.

13. Koral Tasci S, Gulmez N, Aslan S, et al. Immunohistochemical localization of Catalase in Geese (Anser anser) kidney. Kafkas Univ Vet Fak Derg. 2020; 26(1): 41-46, doi: 10.9775/kvfd.2019.22152.

14. Mutus R. Tavuk ve bıldırcında böbrek arterleri. İstanbul Üniv Vet Fak Derg. 1995; 21(1): 59-67.

15. Nickel R, Schummer A, Seiferle E. The anatomy of the domestic birds. 1st ed. Verlag Paul Parley, Berlin, Germany 1977: 40-61.

16. Ozudogru Z, Özdemir D, Balkaya $H$, et al. Civcivlerde Adrenal Bezin Gelişimi Üzerine Farklı Fotoperiyotların Etkisi. Ataturk Univ Vet Bil Derg. 2017; 12(3): 250-258, doi: 10.17094/ataunivbd.295548.

17. Richardson KC, Wooller RD, Casotti G. The relative sizes and asymmetry of kidneys in passerine birds from Australia and North America. J Anat. 1991; 175: 181-185, indexed in Pubmed: 2050563.

18. Romeis B. Microscopic technique. R.Oldenburg, München, Germany 1948: 51-52.

19. Warui CN. Light microscopic morphometry of the kidneys of fourteen avian species. J Anat. 1989; 162: 19-31, indexed in Pubmed: 2808116.

20. Wells JW, Wight PAL. The adrenal glands, In: Physiology and biochemistry of the domestic fowl. Bell DJ and Freeman GM eds. Academic Press, London 1971: 489-520. 